\title{
INNOVATION ACTIVITY AND BUSINESS INCUBATORS BASED ON INSTITUTION OF HIGHER EDUCATION-THE EXPERIENCE OF RUSSIA
}

\author{
Dr Liudmila Gennadyevna Romanovich* \\ Belgorod State Technological University named after V.G. Shoukhov, Russia \\ Dr Evgeniy Ivanovics Evtushenko \\ Belgorod State Technological University named after V.G. Shoukhov, Russia \\ Marina Alexeevna Romanovich \\ Belgorod State Technological University named after V.G. Shoukhov, Russia \\ Dmitriy Victorovich Kudinov \\ Belgorod State Technological University named after V.G. Shoukhov, Russia
}

Russia, as well as advanced foreign countries, wends the way of innovation-based development. The article describes the economic basis to stimulate innovation activity in the system of small business: current problems and development strategy of science and innovation, the concept of innovation and innovation activities, the criteria of small enterprises, to innovate, as well as questions of the theory and practice of business incubators. The authors analyzed the positive experience of the Belgorod State Technological University named after V.G. Shukhov (Russia, Belgorod) in forming at its base innovative business incubator, carrying out infrastructural support of small innovative enterprises established with the participation of students, graduate students, doctoral students and researchers of the university.

Key words: Innovation, Innovative activity, Small innovative business, Business incubator

\section{INTRODUCTION}

In developed countries, the small business sector plays an important role in the social and economic development and improving the well-being of the population, provides a considerable proportion of gross domestic product and employment of population. Small innovative business in advanced foreign countries has become the main object of investment. Consuming 2 to $5 \%$ of the total funding in scientific and technological activities, small knowledge consumptive businesses create $50 \%$ of the major innovations and licensors are almost $50 \%$ of innovation in the global market. In most developing sectors (information technology, electronics, and others.) Of the total number of firms operating small businesses of up to 100 people make up over $80 \%$ [08]. The modern world socio-economic situation is characterized by: the globalization of production and markets, high rates of technological development and modernization, increased requirements to the quality of goods and services, the introduction of unified international standards of quality. But small businesses en masse is not able to realize the full administrative functions. These is especially true of resource support at the start of business and minimize the cost of service management functions, such as market research, search for partners and orders, information and legal support, etc. Therefore, small businesses need stimulation and support from the state and public structures [07]. World practice a combination of measures and forms of stimulation of innovative activity of small businesses is diverse and extensive. A number of industrialized countries choose an innovative path of development: the United States of America, Japan, European Community have formed a certain organizational and economic mechanism to stimulate innovation in the small business. In the last decade as a positive experience in the Russian Federation. Great contribution to the study of innovation processes and the formation of the theory of innovation management made 
by such scholars as J. Schumpeter, A. Drucker, K. Freeman, G. Mensch, A. Klyaynkneht, B. Twist, A. Koyre, B. Santo, D. Mark, N. Kondratiev, R. Fatkhutdinov, Y. Yakovets, V. Antonets, S. Glazyev and others. Nonetheless, many theoretical and methodological and applied aspects in particular of improving the organizational-economic mechanism to stimulate innovation in the small business, in our opinion, been sufficiently developed. In this regard, the study of theoretical and methodological and scientific-practical problems of perfection of the mechanism, as well as international experience in this field is very relevant and is of particular practical importance. The task of forming and actualization the preconditions for innovative development of the Russian regions belongs to the category of strategic importance because of the increasing role of innovation as a key factor in modern socioeconomic development. As economists point out, among the causes of the economic growth of developed countries of the world today, the share of scientific and technical progress has to $80-85 \%$. The problem of providing the high innovation activity and innovative technological breakthrough in the Russian economy are largely objective and caused serious structural imbalances of the soviet economy, the complexity and duration of the formation of a new institutional environment. To ensure the same high rates of growth and stability necessary to carry out innovative renewal of obsolete fixed assets and products, improve the competitiveness of domestic goods and services in the domestic and foreign markets, the transition to the innovative development of the country, as envisaged in the strategy of innovative development of the Russian Federation for the period up 2020. The document specified that one of the main factors of the strategy is the development of innovative infrastructure for transfer of the results of research and development sector in the Russian and global economies, especially by encouraging the creation of small and medium-sized technology innovation companies. [04] Although the availability of publications by innovation problematic issues, have not all yet aspects are studied in depth. In particular, the discussion at the present stage is the theme of the formation of basic universal definitions of "innovation" and "innovation activity". The results showed that in 1999, a draft federal law "On innovation activity and about innovation public policy" was rejected by the Pres- ident of the Russian Federation for the reason to the fuzziness of the concept "innovation activity" and, therefore, unavailability to determine the subject of regulation. The draft federal law "innovation" was defined as the performance of work and (or) services. Said draft federal law has not come into legal force. Many of territorial entity of the Russian Federation exercise abovenoted right, taking in the period from 1997 to 2011 laws governing innovation activities on their territories, which are systematized in the affixation. It seems, at first glance, that formed a conflict of law: the territorial entity of the Russian Federation went beyond its powers. But, according to lawyers, the laws adopted in the regions, does not conflict with federal law, as at the federal level at the time was not passed such a law. It should be noted that the amendment of the Federal Law of July 21, 2011 № 254-FL "About introduction of amendments to Federal Law «On science and national scientific-technical policy» these concepts introduced in regulatory. By reference to the Federal Law, innovation is understood to introduce into practice a new or significantly improved product (goods and services) or process, a new sales method or a new organizational method in business practices, workplace organization or external relations. Innovation activity - activity (including scientific, technological, organizational, financial and commercial activities), aimed at the implementation of innovative projects, as well as the creation of an innovative infrastructure and maintenance of its activities. Studies have shown that the majority of territorial entity of the Russian Federation until 2011 were introduced the concept of "innovation" and "innovation activity" in the regulatory turnover at the regional level, but so far not been harmonized with the federal law "On science and national scientific-technical policy", differ and the last and turn up a debatable. Thus, in accordance with the Law of the Belgorod region, innovative activity - activity related to the transformation of ideas (the results of scientific research, development, development activities or other scientific and technological achievements) into a new or improved product, a new or improved process, implemented in economic turnover, including in the field of bioenergy and biotechnology. Innovation - the eventual result of the creative work that gets realized in the form of new or improved products or new or improved technological process used in economic turnover [03]. It should 
be noted on the international approach to these definitions. The Organization for Economic Cooperation and Development (OECD) is a unique forum where the governments of 30 democracies work together to address the economic, social and environmental challenges of globalization. The countries - members of the OECD are: Australia, Austria, Belgium, Britain, France, Germany, Greece, Denmark, Ireland, Iceland, Spain, Italy, Canada, Republic of Korea, Luxembourg, Mexico, Netherlands, New Zealand, Norway, Poland, Portugal, Slovakia, USA, Turkey, Finland, France, Czech Republic, Sweden, Switzerland and Japan. The Commission of the European Communities takes part in the work of the OECD. "Manual for the Development of data collection and analysis on innovation (The Oslo Manual)" - is the main methodological document of the OECD in the range of innovation for the countries directly involved in the activities of the OECD and a number of countries in Eastern Europe, Latin America, Asia, Africa, is not yet a members of the organization. In accordance with chapter 3 of "Basic definitions" the Oslo Manual "Innovation - is an introduction to use some a new or significantly improved product (good or service) or process, a new marketing method or a new organizational method in business practices, workplace engineering or foreign contacts". The minimum requirement is a sign of innovation to product, process, marketing method or organization was new (or significantly improved) to the practice of the enterprise. This includes the category of innovation products, processes and methods that the company created the first and / or products, processes and techniques borrowed from other companies or organizations. Innovative activities are all scientific, technological, organizational, financial and commercial activities, leading to the actual implementation of the innovation or conceived for this purpose. Some kind of innovation activities are themselves innovative, others do not have this property, but is also necessary for the implementation of innovations. Innovative activities include research and development, not directly related to the preparation of any particular innovation. A common feature of innovation is that it must be put into use (implemented). New or improved product is introduced into use after it appeared on the market. New manufacturing processes, marketing methods or organizational methods are introduced in the use of (embedded) after they have really used in the enterprise. [05].
From the above it can be concluded that the concept of "innovation" and "innovation activity", adopted in 2011 by the Federal law "On science and national scientific-technical policy" respond the Oslo Manual. At this rate, the formation of mechanisms to stimulation of innovation activity based on Universities comes amid discussions of scientists, economists, lawyers on the essence of the basic definitions of "innovation" and "innovation activity", which only in 2011 introduced into the legal turnover at the federal level. At the same time, made before 2011 in territorial entity of the Russian Federation at the regional level laws contain different interpretations of these concepts. In this regard, it is difficult and often and often - it is impossible to concentrate the various resources in the desired direction. The Russian legislation is meant for small business be understood entrepreneurial activity by subjects of small businesses in accordance with the criteria of the Federal Law № 209-FL dated 24 July 2007 [01]:

- Legal entities whose authorized capital share of the Russian Federation, territorial entity of the Russian Federation, municipal formation, foreign juridical person, foreign citizens, social and religious organizations, charitable and other funds does not exceed $25 \%$; share belonging to one or more legal entities which are not small businesses, does not exceed $25 \%$; average number of employees per year - less than 100 people; Revenue from sale of goods (services) for the year - 400 million rubles;

- Individuals engaged in entrepreneurial activities without a legal entity and observe the criteria of size and revenue.

Effective means in reducing failures in business, increasing the proportion of surviving new businesses are incubators - a type of specialized infrastructure to provide support of small business along with technology parks, foundations, business centers, educational, informational and other service agencies. The Government Decree of April 22, 2005 №249 «On the conditions and the procedure for granting in 2005 of federal budget funds allocated for state support of small business, including peasant (farmer's) economy, introduced the following definition: business incubators - organizations created to support entrepreneurs in the early stages of their activities through the provision of premises and the provision of consulting, accounting and legal services. [02] 
Here are a few definitions of the concept. Business Incubator is:

- The subject of innovation infrastructure created for the purpose of the formation of new businesses, job creation and economic development in an integrated method of organization of the innovation process (Eurasian Council for Standardization, Metrology and Certification) [07];

- A program of comprehensive care for young newly organized enterprises, aimed to support them by creating favorable conditions for their establishment and successful development of the (National Association of Business Incubators USA) [06].

According to the National Business Incubation Association USA in the world currently operates about 4 thousand business incubators. Such structures exist in 67 countries, including the United States - 981 Incubator, Chile - 400, Germany - 380, Korea - 289, Japan - 269, etc. In most industrialized countries (USA, Germany, Italy, China, Finland, and others.) Business incubators receive substantial state aid, some of them adopted specific laws defining the status and regulating activity. Business incubators in Russia began to emerge in the period after 1991, based on international experience, in the framework of the Morozov project. Ideology of the past had been the Academy of Management and Market, and several business incubators organized grant the United States and Canada. At the beginning of 2011 in the Russian Federation, there are about 150 business incubators that are not enough to achieve this goal - the creation of an economy based on knowledge. Creating a business incubator can pursue different goals. It is - to promote the effective use of scientific and technological potential, creation of new jobs (adequate training of scientific, engineering and technical personnel and specialists), development and implementation of innovative projects, the provision of investment, financial and business support, promote environmental protection, conversion, reconstruction and the restructuring of industrial enterprises. Business incubator can be formed on the basis of higher education (university) research institute, scientific and industrial organization or group of organizations. Business incubator performs the following functions:

- Leasing of premises and providing office services (office space, support and manufacturing facilities, exhibition areas, ensur- ing the functioning of different kinds of communication, availability and office equipment for communities; the provision of postal and secretarial services);

- Comprehensive and competent consulting service for small businesses at different stages of development;

- Providing advice to budding small firms on economic, legal and technological issues;

- Providing targeted methodological and educational support to small businesses;

- Creation of conditions for the expansion of inter-regional cooperation of small enterprises.

One of the most important advantages of the activities of business incubators - the formation of professional standards among business entrepreneurs. Instill entrepreneurs to adopt a habit, initially mainly struggling for survival, to highest professional standards of doing business is not easy. Business incubators are designed to teach entrepreneurs and management staff of small businesses to a certain standard paperwork, the preparation of promotional and advertising materials, to negotiate with partners and customer service at the highest professional level. Turning growing small business of domestic craft industry in a professional, business-incubator provides the basis of formation of the civilized class of entrepreneurs. In the creation of business incubators interested universities, as well as bodies of the central governmental authorities, regional and local governments, which are usually the initiators of projects or actively support them in the development of regional innovation systems. Universities receive an effective mechanism for the transfer of technology from science to industry. Incubator - a place of realization of the idea of scientists, teachers and students, engineers and innovators and entrepreneurs. Part of me, and the educational process, it becomes a market-oriented, aimed at training not just engineers, entrepreneurs and engineers. At the moment in Russia it is successfully operating a whole series of business incubators created in the last decade, and assisting in the development of hundreds of small businesses. One of the leaders among them is an innovative business incubator, Belgorod State Technological University named after V.G. Shukhov (Belgorod). The main objectives of the innovative business incubator of the University:

- increase in the number of small businesses in the area of high technologies, created with 
the participation of students and researchers on the basis of Belgorod State Technological University named after V.G. Shukhov and increase their sustainability;

- Facilitating the access of small businesses to the logistical and other resources in the field of high technologies;

- The formation of standards of professional business among small businesses.

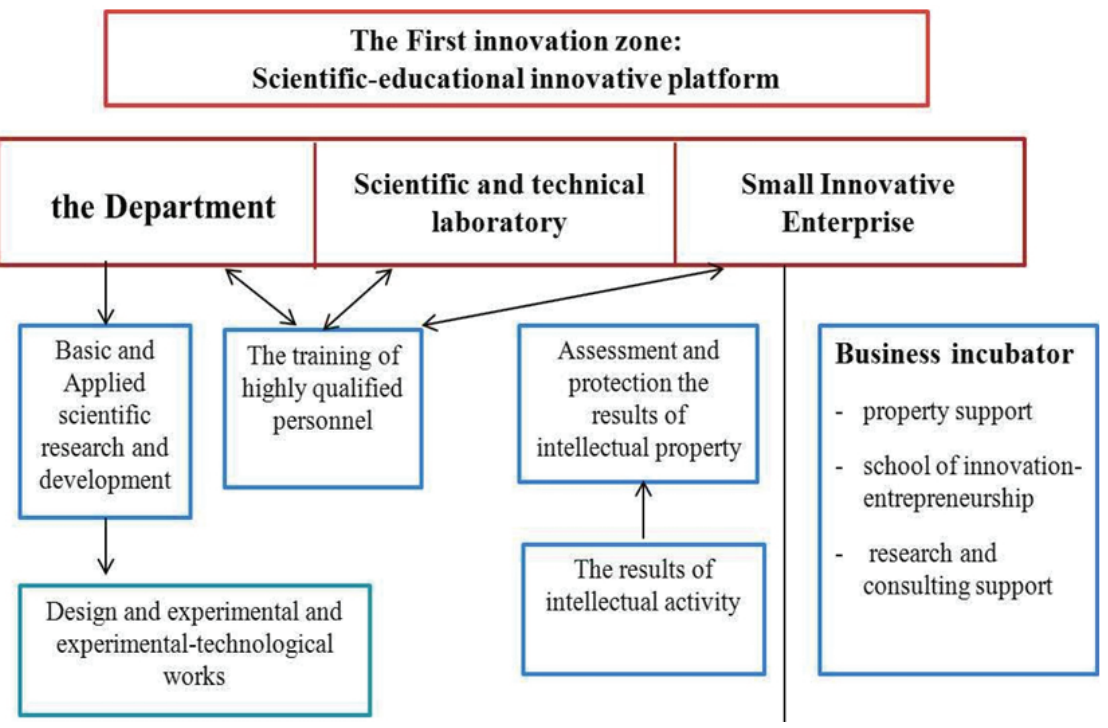

Figure 1. Infrastructure support for Small innovative enterprises on the basis of the early stages of development of Belgorod State Technological University named after V.G. Shukhov

Priority organizations to provide full support in the business incubator based Belgorod State Technological University named after V.G. Shukhov are budding small businesses working in the field of high technologies. Staying in an innovative business incubator, small businesses have an opportunity to innovate using innovative platforms on preferential terms. The company is



Figure 2. The number of small innovative enterpries at the University

Today, participants in the innovation business incubator are 106 small enterprises. These companies operate in the field of energy efficiency, nanotechnologies, IT and information technology, new materials and equipment, "BetonProekt", "Inno- located in the innovative business incubator for 3 years and use scientific and consulting services on favorable terms. At the end of 3 years - unproven companies leave innovation business incubator. The number of small innovative enterprises at the University concluded license contracts these companies and their earnings are presented in figures 2 and 3 .

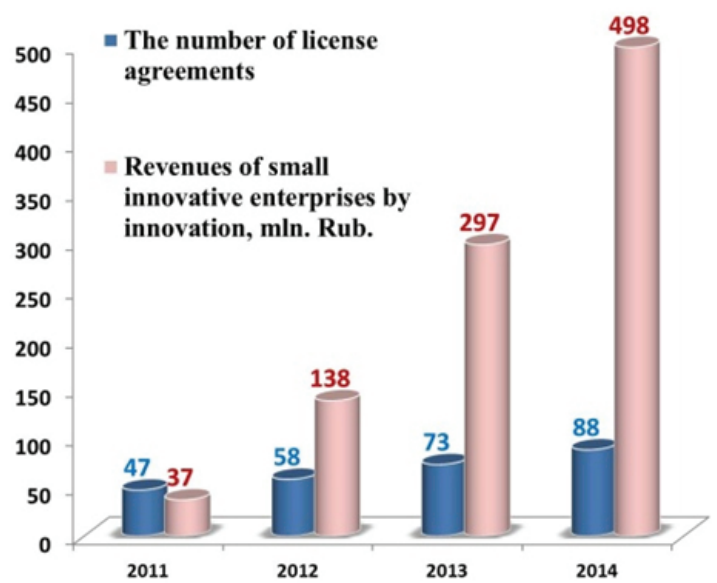

Figure 3: The number of license agreements and income of small innovative enterprises

vative technologies and equipment engineering", "Rostehkeram", "NPP Analitsistemy", "Recycle-Intech", "SEC Modern integrated automation techniques "," FIT-Intellect "," BelSilika "and others. According to the Russian Ministry of Education 
in terms of the development of small innovative enterprises Belgorod State Technological University named after V.G. Shukhov took third place in the Russian Federation. The authorized capital of these companies made of the right to use the intellectual property of the university: inventions, utility models, computer programs. Also, small innovative businesses are research and consulting support in the framework of the "Business Center" and learn the basics of innovative entrepreneurship in the "School of Entrepreneurship Education in the field of high technology."

\section{CONCLUSION}

Thus, in light of the problems indicated by the author identified an urgent need for harmonization of regional legislation and methodological instrumentarium with federal, defining a common understanding of innovation, innovation activities, which will provide:

- Common methodological approaches for collecting information on small innovative enterprises engaged in innovative activities in Universities;

- The accuracy of the information about the innovative activities of small innovative enterprises and comparability of the results and assessments in the field of innovation with foreign countries;

- The ability to focus in the right direction financial, material, administrative and other resources;

- Ensure the improvement of federal, regional and municipal programs to support small innovative enterprises at universities, including in terms of not only supports small businesses operating in the field of technological innovation, but also developing and implementing a new method of sales, a new organizational method in business practices, organization jobs, or in external relations;

- Development and improvement of infrastructure to support small businesses in universities.

- Thus, the innovative business incubator BSTU named after V.G. Shukhov was the most important object of infrastructure support innovation in the Belgorod region and Russia. In our opinion, the positive experience of business incubation on the basis of BSTU named after V.G. Shukhov may be useful to other regions of the Russian Federation and foreign states.

\section{ACKNOWLEDGEMENTS}

The authors extend acknowledgements to the rector of BSTU named after V.G. Shukhov, prof. Sergei Nikolayevich Glagolev for their assistance in organizing the study and publication of the results. Work has been performed in the framework of Strategic Development Program at BSTU named after V.G. Shukhov for 2012-2016.

\section{REFERENCES}

1) Federal Law of 24 July № 209-FZ (2007). On the development of small and medium enterprises in the Russian Federation.

2) Government Decree of April 22 № 249 (2005). On the conditions and the procedure for granting in of federal budget funds allocated for state support of small business, including peasant (farmer's) economy.

3) The Law of the Belgorod region of 1 October № 296 (2009). On innovation and innovation policy in the Belgorod region.

4) Approval of the strategy of innovative development of the Russian Federation for the period up to 2020 (2011): Order of the Government of the Russian Federation of December 08 № 2227- Garant System (CD-ROM).

5) Oslo Manual "Guidelines for collecting and analyzing data on innovation", 2010. Third edition. Published under an agreement with the OECD, the Paris, Russian edition carried a state institution "Center of Science Research and Statistics" [CSRS] Ministry of Education of the Russian Federation.

6) Report of the President of the National Association of Business Incubators United States at the International Conference "The interaction of small and large businesses", 2010. Moscow.

7) Romanovich, L.G., Rudychev, A.A. and Romanovich, M. A., 2013. Incentives for innovative activity of young scientists on the basis of Higher Educational Institutions in Russia. Experience of Belgorod State Technological University named after V.G. Shukhov. World Applied Sciences Journal, 25 (12): 1754-1757.

8) Romanovich, M.A., Evtushenko, E. I. and Romanovich, L.G., 2013. Promoting innovation youth on the basis of higher education institutions. "Bulletin of Belgorod State Technological University named after V.G. Shukhov", 5: 150-152.

Paper sent to revision: 09.04.2015.

Paper ready for publication: 14.09.2015. 